
Kada grafted on different Solanaceae species and control of bacterial wilt. Horticultura Brasileira 36: 377-381. DOI - http://dx.doi.org/10.1590/S0102053620180315

\title{
Compatibility of tomato cultivar Santa Cruz Kada grafted on different Solanaceae species and control of bacterial wilt
}

\author{
André R Zeist ${ }^{1}$; Clevison L Giacobbo ${ }^{2}$; Gentil F da Silva Neto ${ }^{3}$; Ricardo A Zeist ${ }^{1}$; Keilor da R Dorneles ${ }^{4}$; \\ Juliano TV de Resende ${ }^{1}$
}

${ }^{1}$ Universidade Estadual do Centro-Oeste do Paraná (UNICENTRO), Guarapuava-PR, Brazil; andre.zeist@bol.com.br; jresende@unicentro. br; ricardo-zeist@bol.com.br; ㄴniversidade Federal da Fronteira Sul (UFFS), Chapecó-SC, Brazil; clevison.giacobbo@uffs.edu.br; ${ }^{3}$ Universidade Federal do Rio Grande do Sul (UFRGS), Porto Alegre-RS, Brazil; neto.gentilfelix@hotmail.com; ${ }^{4}$ Universidade Federal de Pelotas (UFPel), Capão do Leão-RS, Brazil; keilor.rd@hotmail.com

\begin{abstract}
The objective of this work was to evaluate the compatibility, gas exchange and yield of tomato cultivar Santa Cruz Kada, susceptible to bacterial wilt (Ralstonia solanacearum) when grafted on different Solanaceae species. Rootstock sources were the mini-tomato RVTC66, Cayenne pepper, Jerusalem cherry (Solanum pseudocapsicum), sticky nightshade (Solanum sisymbriifolium), and cultivar Santa Cruz Kada itself (self-grafting). Two materials were tested to promote the union between rootstocks and scions: grafting clips and biodegradable tape (Parafilm). Grafting success index (GSI) was evaluated and, for treatments using biodegradable tape, grafting incompatibility, gas exchange, agronomic characteristics and bacterial wilt epidemiology were assessed throughout the cycle. The use of biodegradable tape favored graft healing. Cayenne pepper, Jerusalem cherry, and sticky nightshade should not be employed as rootstocks for scions of tomato cultivar Santa Cruz Kada. The mini-tomato accession RVTC-66 showed low graft incompatibility, high photosynthetic efficiency and, when compared to self-grafting, the same fruit production, but with higher plant health index concerning the bacterial wilt.
\end{abstract}

Keywords: Solanum lycopersicum, Ralstonia solanacearum, photosynthesis, grafting, production.

\section{RESUMO}

Compatibilidade do tomateiro Santa Cruz Kada enxertado em solanáceas e controle da murcha bacteriana

O objetivo do trabalho foi avaliar a compatibilidade, trocas gasosas e produtividade do tomateiro Santa Cruz Kada, suscetível à murcha bacteriana (Ralstonia solanacearum), enxertado em diferentes solanáceas. Foram utilizados como porta-enxertos o acesso de minitomate RVTC-66, a pimenta cultivar Cayenne, a peloteira (Solanum pseudocapsicum), o juá (Solanum sisymbriifolium) e o próprio tomateiro cultivar Santa Cruz Kada (autoenxertia). Também foram testados dois materiais para união das plantas no ponto de enxertia: clipes de enxertia e fita biodegradável (Parafilm). Foi avaliado o índice de pegamento de enxertia (IP) e, para as mudas enxertadas utilizando fita biodegradável, foram avaliadas, ao longo do ciclo, compatibilidade de enxertia, trocas gasosas, características agronômicas e epidemiologia da murcha bacteriana. Considerando os resultados obtidos, a fita biodegradável favoreceu a cicatrização da enxertia. Não se recomenda a utilização da pimenta cultivar Cayenne, da peloteira e do juá como porta-enxertos. O acesso de minitomate RVTC-66 apresentou boa compatibilidade de enxertia, com bom rendimento fotossintético e, em comparação à autoenxertia, a mesma produção de frutos e aumento do índice de sanidade relativo à murcha bacteriana.

Palavras-chave: Solanum lycopersicum, Ralstonia solanacearum, fotossíntese, enxertia, produção.

\section{Received on February 20, 2018; accepted on October 16, 2018}

$\mathrm{G}$ rafting is widely used to produce seedlings of plant species from Solanaceae and Cucurbitaceae families (Lee et al., 2010) with the primary purpose of conferring resistance to soilborne diseases (Gilardi et al., 2013). The use of adequate rootstocks may also contribute to tolerance to salinity and abrupt temperature fluctuations (Venema et al., 2008; Abdelmageed \& Gruda, 2009; Flores et al., 2010), to increase efficiency in water absorption and nutrient use (Santa-Cruz et al., 2002), to improve physiological performance (Abdelmageed \& Gruda, 2009), to prolong harvest period and to increase yield and fruit quality (Flores et al., 2010). Grafting is an alternative to control bacterial wilt caused by Ralstonia solanacearum, the main limitation to tomato production (Lopes et al., 2015). In this case, it has the additional advantage of not demanding drastic changes in crop management.

Bacterial wilt induces turgor loss in young leaves during the hottest period of the day, which may or may not recover overnight. Wilting results from clogging of the xylem caused by accumulation of polysaccharides produced by the bacteria, which multiplies in the plant vascular system. Depending on the disease severity, the whole plant 
may irreversibly wilt and then die (Almoneafy et al., 2013).

It is possible to employ resistant rootstocks belonging to another genotype of $L$. solanum or from some other Solanaceae species to control the bacterial wilt in tomato (Lopes et al., 2015). Rootstocks must present good morphological, physiological and chemical affinity with the scion, in addition to resistance to the soil adverse conditions. The limited availability of resistant rootstocks to bacterial wilt and excellent compatibility with tomato susceptible cultivars is the primary obstacle to the use of grafting in tomato (Peil, 2003; Farias et al., 2013).

The difference between compatibility and incompatibility in grafting is not well defined yet. There is a healing gradation at the grafting point and, with time, plants may present disorder symptoms or abnormal growth (Peil, 2003; Martínez-Ballesta et al., 2010). Grafting compatibility is assessed through physiological characteristics of the scion (Rodrigues et al., 2001) and stem diameter at the grafting point (Giacobbo et al., 2007; Farias et al., 2013). However, in non-woody plants, little is known about the rootstock influence over the physiological behavior of the scion (Martínez-Ballesta et al., 2010), as it is the case for several Solanaceae species.

Some Solanaceae, including some tomato accessions, do not produce fruits of economic value. However, many of these accessions present vigorous plants, with resistance to pathogens and tolerance to limiting edaphoclimatic conditions, especially extreme temperatures, drought and high humidity and salinity (Farias et al., 2008; Petran \& Hoover, 2014). Considering these aspects, such plants, including mini-tomato accessions, can be potentially used as rootstocks for different Solanaceae. The most used grafting methods in tomato are splice and tongue insertion, although other techniques can also be employed (Lee et al., 2010). Splice consists of the union between scion and rootstock, fixing one to the other with materials such as clips and tapes until complete healing (Lee et al., 2010). The method is highly successful when grafted seedlings are kept under conditions of mild temperature and high humidity (Goto et al., 2010).

The objective of this work was to evaluate compatibility characteristics, gas exchange and yield of Santa Cruz Kada tomato, susceptible to bacterial wilt, grafted on different Solanaceae.

\section{MATERIAL AND METHODS}

The experiments were carried out in the season 2011/2012, in greenhouse conditions, at Federal University of Pampa, in Itaqui $\left(29^{\circ} 09^{\prime} \mathrm{S}, 56^{\circ} 33^{\prime} \mathrm{W}, 82\right.$ m altitude), state of Rio Grande do Sul.

Scions from cultivar Santa Cruz Kada, susceptible to Ralstonia solanacearum, were grafted using the splice method in rootstocks from five different sources. The experiment was carried out in a completely randomized design, with treatments arranged in a $5 \mathrm{x}$ 2 factorial design (rootstocks $x$ materials for promoting the graft union), with ten replications, and five-plant plots. Rootstock sources were mini-tomato accession RVTC-66 (germplasm bank of the Horticulture Research Center of UNICENTRO), pepper cultivar Cayenne (ISLA Seeds), Jerusalem cherry (Solanum pseudocapsicum), sticky nightshade (Solanum sisymbriifolium) and the tomato cultivar Santa Cruz Kada (self-grafting). Grafting clips and biodegradable tape (Parafilm) were evaluated to promote the graft union.

Seeds of the rootstocks and scions were sown in expanded polystyrene 200-cell trays containing a commercial substrate and kept in floating type hydroponic system. The mini-tomato RVTC-66 and cultivar Santa Cruz Kada were sown on August 11, 2011; cayenne pepper and sticky nightshade, 21 days before and, Jerusalem cherry, approximately six months earlier. Seedlings were transplanted into $180 \mathrm{~mL}$ plastic cups, containing commercial substrate, 23 days after scion emergence, keeping one seedling of rootstock and one of scion per cup. Grafting was performed four days later, when seedlings had three to four fully expanded leaves, using carbon steel blades, material to promote plant union (biodegradable tape and clips) and wooden sticks to tutor the plants.

Grafted plants were kept in a floating type humid chamber for 15 days after grafting (DAG) and then transferred to a greenhouse bench, when we removed lateral shoots and aboveground part of the rootstocks. Graft clips and bases were taken away 18 DAG (weaning). The grafting success index (GSI), expressed as percentage, was calculated on the same date by counting the number of healed grafts and the total number of grafted plants. Grafts in which the biodegradable tape was used were transplanted $23 \mathrm{DAG}$ to $10 \mathrm{dm}^{3}$ pots, containing sieved Eutric Leptosol (FAO, 1994), naturally infested with $R$. solanacearum, and carbonized rice husk, in 3:1 parts. The infected soil was collected on a farm, from a greenhouse where tomato was continuously cultivated, and plants with symptoms of $R$. solanacearum were present in the last five crops.

Pots were kept in the greenhouse, in completely randomized design, with four replications and plots of eight grafted plants. The $\mathrm{pH}$ of the mixture soil:rice husk was adjusted using 4.12 $\mathrm{g}$ of dolomitic limestone ( $75 \%$ CCE) per pot. Plants were conducted with the main stem and vertically staken, with micro-dripping irrigation and fertigation according to Andriolo (1999).

Grafting incompatibility (GI) was evaluated 30 and 60 days after transplanting (DAT), assessing the diameters of the rootstock stem (RD), of the grafting point (DPoG) and of the scion (SD), $\pm 1 \mathrm{~cm}$ above and below the grafting point. The GI was estimated using the formula:

$$
\mathrm{GI}=\{(\mathrm{RD}-\mathrm{SD})+[(\mathrm{DPoG}-\mathrm{SD})+(\mathrm{DPoG}-
$$
$\mathrm{RD})] / 2\} / 2$

The plant survival rate (SR), e.g., percentage of surviving plants 30 and 60 DAT relatively to the total number of grafted plants, was also calculated. The following characteristics were additionally assessed: plant height $(\mathrm{PH})$, from stem base to apex $(\mathrm{cm})$ at the time of transplanting and 30 and 60 DAT; gas exchanges measured by means of a portable infrared gas analyzer (IRGA), with $1000 \mu \mathrm{mol}$ 
photons $\mathrm{m}^{-2} \mathrm{~s}^{-1}, 400 \mu \mathrm{mol} \mathrm{mol} \mathrm{m}^{-1}$ of $\mathrm{CO}_{2}$ and $\Delta \mathrm{CO}_{2}+\Delta \mathrm{H}_{2} 0$ below $1 \%$, used to determine the photosynthetic efficiency (A, $\left.\mu \mathrm{mol} \mathrm{CO} \mathrm{m}^{-2} \mathrm{~s}^{-1}\right)$ and the transpiration rate $\left(\mathrm{E}, \mathrm{mmol} \mathrm{H}_{2} \mathrm{O}\right.$ $\mathrm{m}^{-2} \mathrm{~s}^{-1}$ ); and water use efficiency (WUE, mmol $\mathrm{H}_{2} \mathrm{O}^{-1}$ ), estimated by the relation between $\mathrm{A}$ and $\mathrm{E}$ in fully expanded leaves from the central third of plants.

Only fruits in the light red maturation stage were considered in each harvest to estimate the production characteristics. The number of commercial fruits (NCF) was obtained by summing the number of fruits collected in all harvests; the commercial fruit production (CFP) $\left(\mathrm{kg} \mathrm{plant}^{-1}\right)$ corresponded to the fruit accumulated production in all harvests and; average mass of commercial fruits (AMCF) ( $\mathrm{g}$ fruits ${ }^{1}$ ) was estimated from the relation $\mathrm{CFP} / \mathrm{NCF}$ in each harvest.

The epidemiological analysis of bacterial wilt was performed according to Pena et al. (2010), at weekly intervals, recording the plants with at least $50 \%$ wilted leaves. Resistance to the pathogen was estimated using the plant health index (PHI) and, the infection rate (QR), according to Plank (1963). The following formula provided the PHI: $\mathrm{PHI}=\mathrm{SP} / \mathrm{TP}$, where SP is the number of symptomless plants and TP is the total number of plants in the plot. The following formula resulted in the QR index (Plank, 1963):

$$
Q R=\frac{1}{t_{2}-t_{1}}\left(\log _{e} \cos \frac{1}{1-I D_{2}}+\log _{e} \frac{1}{1-I D_{1}}\right)
$$

where: ID (disease index $)=1$ - SI (Noda et al., 1986); t 1 = number of days between transplant and first evaluation; $\mathrm{t} 2=$ number of days between transplant and last evaluation; $\mathrm{ID}_{1}=$ disease index in the $1^{\text {st }}$ evaluation and; $\mathrm{ID}_{2}=$ disease index in the last evaluation.

Data were tested for normality and homogeneity and then submitted to analysis of variance. In case of significant $F$ values, treatment means were compared by Tukey test at $5 \%$ probability or by t-Student test, also at $5 \%$, when only two treatments were present. Data expressed as percentage were transformed into arc sine of $(\mathrm{x} / 100)^{1 / 2}$. Analyzes were performed using the software ASSISTAT version 7.7, 2014 (Silva, 2014).

\section{RESULTS AND DISCUSSION}

The interaction between sources of rootstock and materials for the union between scions and rootstocks was significant for the grafting success index (GSI). Self-grafting and the mini-tomato RVTC-66 rootstock, when combined with biodegradable tape, presented the highest values for GSI, $100.0 \%$ and $96.0 \%$, respectively. These same rootstocks and Cayenne pepper, when grafted with grafting clips, presented better results than the other rootstocks: GSI of $72.0 \%$, in contrast to the other rootstocks which had GSI $<52 \%$ (Table 1). The GSI of $100 \%$ for self-grafting using the biodegradable tape demonstrates that this material favors healing. The lower GSIs observed for rootstocks from Cayenne pepper, Jerusalem cherry, and sticky nightshade compared to the use of scions and rootstocks of the same species indicated that it is not always possible to obtain satisfactory grafting rates when scions and rootstocks come from different species, even when belonging to the same botanic family. The low affinity between tomato scions and rootstocks from other Solanaceae agrees with Martínez-Ballesta et al. (2010), who state the formation of healing vascular connections between rootstocks and scions do not always happen; and, in some cases, connections are deficient due to species incompatibility.

The use of biodegradable tape is frequent in the grafting of fruit crops. The tape promotes good healing rates and, additionally, it does not need to be removed after healing. Still, it is less frequently used in the grafting of
Solanaceae species than grafting clips, which are practical and, contrary to the tape, can be used several times. Nevertheless, grafting clips resulted in a lower grafting success index when compared to the tape in the current experiment. Producers of grafted tomato seedlings should consider all these relevant aspects when choosing the most practical and less expensive material to promote healing (Lee et al., 2010).

There were no significant differences for grafting incompatibility (GI) at the date of transplanting. However, already 30 days after transplanting (DAT), rootstocks from Cayenne pepper, Jerusalem cherry, and sticky nightshade showed significantly higher grafting incompatibility with tomato than rootstocks from the mini-tomato RVTC-66 and from tomato Santa Cruz Kada itself, the self-grafting (Table 2). Rootstocks from Cayenne pepper, Jerusalem cherry, and sticky nightshade had low survival rates (SR) of grafted plants $30 \mathrm{DAT}$, progressing to complete death of grafted plants 60 DAT. In contrast, all grafts involving the minitomato RVTC-66, as well as the selfgrafting, survived (Table 2).

Grafting incompatibility and death of all plants grafted on Cayenne pepper, Jerusalem cherry, and sticky nightshade corroborate Peil (2003) who observed that not all plant species have morpho-physiological characteristics that favor grafting. The use of tomato accessions as rootstocks has the significant advantage of reducing the incompatibility frequently observed when rootstocks from other species and genera are used with tomato scions (Lopes et al., 2015). Similar results

Table 1. Grafting success index for tomato cultivar Santa Cruz Kada grafted on different Solanaceae, with the use of two materials for the union between scions and rootstocks. Itaqui, UNIPAMPA, 2011.

\begin{tabular}{lccccc}
\hline & \multicolumn{5}{c}{ Rootstocks } \\
\cline { 2 - 6 } Union material & RVTC-66 & $\begin{array}{c}\text { Cayenne } \\
\text { pepper }\end{array}$ & $\begin{array}{c}\text { Jerusalem } \\
\text { cherry }\end{array}$ & $\begin{array}{c}\text { Sticky } \\
\text { nightshade }\end{array}$ & $\begin{array}{c}\text { Self- } \\
\text { grafting }\end{array}$ \\
\hline Biodegradable tape & $96.0 \mathrm{Aa}$ & $48.0 \mathrm{Bb}$ & $52.0 \mathrm{Ab}$ & $44.0 \mathrm{Ab}$ & $100.0 \mathrm{Aa}$ \\
Grafting clips & $72.0 \mathrm{Ba}$ & $72.0 \mathrm{Aa}$ & $48.0 \mathrm{Ab}$ & $40.0 \mathrm{Ab}$ & $72.0 \mathrm{Ba}$ \\
\hline CV (\%) & & \multicolumn{5}{c}{15.3} \\
\hline
\end{tabular}

Means followed by same uppercase letter in the column and same lowercase letter in the line, do not differ significantly from each other by Tukey test, $\mathrm{P}>0.05$. 
were obtained by Farias et al. (2013) with Solanum viarum, incompatible with tomato; by Flaishman et al. (2008), who observed full incompatibility and no differentiation of vascular tissues when grafting Arabidopsis on tomato rootstocks and; by Kawaguchi et al. (2008) who considered pepper and tomato incompatible for grafting. On the other hand, all cited authors also verified good grafting compatibility when a tomato is used both as rootstock and scion.

Plants resulting from self-grafting and from grafting on the minitomato RVTC-66 were taller than plants grafted in the other rootstocks both at transplanting and one month later, keeping normal growth and development up to $60 \mathrm{DAT}$, without differing significantly from each other (Table 2). In contrast, plants grafted on cayenne pepper, Jerusalem cherry and sticky nightshade were shorter and eventually died due to grafting incompatibility.
As for plant height, plants grafted on rootstocks from the mini-tomato RVTC-66 and self-grafted showed higher photosynthetic efficiency (A) than plants grafted on other rootstock sources at transplanting, 30 and 60 DAT (Table 3), with no significant differences between self-grafting and the use of RVTC-66. Higher A values indicate that these plants produced more photoassimilates, which are directed to the growth and development of vegetative and reproductive organs.

Plants grafted on the mini-tomato RVTC-66 had the lowest transpiration rate (E) in all gas exchange evaluations, which points to a higher water use efficiency (WUE) (Table 3). The increase of WUE occurs due to the preservation of the plant photosynthetic rate even with decreases on $E$. Plants with high WUE and $\mathrm{CO}_{2}$ absorption are ideal plants (Jaimez et al., 2005).

The poor $A$ scores of plants grafted in rootstocks of Cayenne pepper, Jerusalem cherry and sticky nightshade agree with the evidence of higher grafting incompatibility and lower plant survival, demonstrating that tissue regeneration after grafting was insufficient in these treatments. According to Martínez-Ballesta et al. (2010), the weak connection of vascular bundles between rootstock and scion can affect the flow of water and reduce plant growth. Plants grafted on RVTC-66 and those self-grafted, which presented $100 \%$ SR, did not differ from each other on the evaluated agronomic characteristics, with average results of 44.1 commercial fruits per plant, yields of $4.1 \mathrm{~kg} \mathrm{plant}^{-1}$ and fruit mean weight of $95.8 \mathrm{~g}_{\text {fruit }}{ }^{-1}$. Harvesting started 72 DAT and finished 91 DAT, for both rootstocks.

There were favorable conditions for the development of bacterial wilt (Ralstonia solanacearum). First symptoms were diagnosed 62 DAT in self-grafted plants and 73 DAT in plants grafted on the mini-tomato RVTC-66. The plant health index (PHI) of plants

Table 2. Grafting incompatibility (GI), plant survival rate (SR) and plant height (PH) of tomato grafted on different Solanaceae. Itaqui, UNIPAMPA, 2011.

\begin{tabular}{|c|c|c|c|c|c|c|c|}
\hline \multirow{2}{*}{ Rootstock } & \multicolumn{2}{|c|}{$\overline{\text { GI }}$} & \multicolumn{2}{|c|}{ SR (\%) } & \multicolumn{3}{|c|}{ PH (cm) } \\
\hline & Transplant & 30 DAT & 30 DAT & 60 DAT & Transplant & 30 DAT & 60 DAT \\
\hline RVTC-66 & $1.3 \mathrm{a}$ & $2.4 \mathrm{~b}$ & $100.0 \mathrm{a}$ & $100.0 \mathrm{a}$ & $28.1 \mathrm{a}$ & $128.80 \mathrm{~b}$ & $180.6 \mathrm{a}$ \\
\hline Cayenne pepper & $1.6 \mathrm{a}$ & $11.3 \mathrm{a}$ & $37.5 \mathrm{~b}$ & - & $17.1 \mathrm{~b}$ & $34.80 \mathrm{c}$ & - \\
\hline Jerusalem cherry & $1.5 \mathrm{a}$ & $10.9 \mathrm{a}$ & $6.3 \mathrm{~d}$ & & $12.3 \mathrm{c}$ & $31.22 \mathrm{~cd}$ & - \\
\hline Sticky nightshade & $1.5 \mathrm{a}$ & $11.4 \mathrm{a}$ & $25.0 \mathrm{c}$ & - & $13.8 \mathrm{c}$ & $28.62 \mathrm{~d}$ & - \\
\hline Self-grafting & $1.4 \mathrm{a}$ & $2.4 \mathrm{~b}$ & $100.0 \mathrm{a}$ & $100.0 \mathrm{a}$ & $30.1 \mathrm{a}$ & $139.50 \mathrm{a}$ & $184.4 \mathrm{a}$ \\
\hline $\mathrm{CV}(\%)$ & 12.1 & 9.8 & 15.5 & 0.0 & 18.4 & 16.7 & 10.0 \\
\hline
\end{tabular}

Means followed by same letter in the column do not differ significantly from each other by the Tukey test (GI, SR 30 DAT and PH 30 DAT) and Student test (SR 60 DAT and PH 60 DAT), P $>0.05$. DAT = Days after transplant.

Table 3. Photosynthetic efficiency $(A)$, transpiration rate $(E)$ and water use efficiency (WUE) in tomato grafted on different Solanaceae. Itaqui, UNIPAMPA, 2011

\begin{tabular}{|c|c|c|c|c|c|c|c|c|c|}
\hline \multirow[b]{2}{*}{ Rootstock } & \multicolumn{3}{|c|}{$A\left(\mu \mathrm{mol} \mathrm{CO}_{2} \mathrm{~m}^{-2} \mathrm{~s}^{-1}\right)$} & \multicolumn{3}{|c|}{$E\left(\mathrm{mmol} \mathrm{H}_{2} \mathrm{O} \mathrm{m}^{-2} \mathrm{~s}^{-1}\right)$} & \multicolumn{3}{|c|}{ WUE $\left(\mathrm{mmol} \mathrm{H} \mathrm{H}_{2} \mathrm{~m}^{-2} \mathrm{~s}^{-1}\right)$} \\
\hline & Transplant & 30 DAT & 60 DAT & Transplant & 30 DAT $^{1}$ & 60 DAT & Transplant & 30 DAT $^{1}$ & 60 DAT \\
\hline RVTC-66 & $19.6 \mathrm{a}$ & $19.4 \mathrm{a}$ & $18.3 \mathrm{a}$ & $2.7 \mathrm{~b}$ & $2.2 \mathrm{~b}$ & $3.1 \mathrm{~b}$ & $7.0 \mathrm{a}$ & $8.8 \mathrm{a}$ & $5.9 \mathrm{a}$ \\
\hline Cayenne pepper & $18.4 \mathrm{~b}$ & $12.4 \mathrm{~b}$ & - & $3.0 \mathrm{a}$ & $3.2 \mathrm{a}$ & - & $6.1 \mathrm{~b}$ & $3.9 \mathrm{c}$ & - \\
\hline Jerusalem cherry & $18.6 \mathrm{~b}$ & $11.9 \mathrm{~b}$ & - & $3.1 \mathrm{a}$ & $3.3 \mathrm{a}$ & - & $6.0 \mathrm{~b}$ & $3.6 \mathrm{c}$ & - \\
\hline Sticky nightshade & $18.3 \mathrm{~b}$ & $11.7 \mathrm{~b}$ & - & $3.0 \mathrm{a}$ & $3.4 \mathrm{a}$ & - & $6.1 \mathrm{~b}$ & $3.4 \mathrm{c}$ & - \\
\hline Self-grafting & $19.5 \mathrm{a}$ & $19.2 \mathrm{a}$ & $18.1 \mathrm{a}$ & $2.9 \mathrm{a}$ & $3.1 \mathrm{a}$ & $5.1 \mathrm{a}$ & $6.4 \mathrm{~b}$ & $6.2 \mathrm{~b}$ & $3.5 \mathrm{~b}$ \\
\hline CV (\%) & 15.4 & 15.4 & 7.2 & 14.2 & 14.1 & 8.2 & 15.1 & 15.2 & 7.7 \\
\hline
\end{tabular}

Means followed by same letter in the column do not differ significantly from each other by the Tukey test $(A, E$ and WUE, Transplant and 30 DAT) and the Student test $(A, E$ and WUE, 60 DAT), P $>0.05$; DAT $=$ Days after transplant. 
grafted in the RVTC-66 rootstock was 0.60 , significantly higher than that observed in self-grafting (0.95). These scores demonstrate that the accession of mini-tomato RVTC-66 was effective in decreasing the infection potential of the bacterial wilt pathogen in the tomato cultivar Santa Cruz Kada when used as rootstock. The infection rates (QR) observed both in the treatment with RVTC-66 (0.0071) and in the self-grafting (0.0090) did not differ significantly from each other, although disease severity evolved very rapidly in the susceptible self-grafted plants.

Although the commercial hybrids Guardião, Protetor, Muralha (Takii of Brazil) and Magnet (Sakata Seed Sudamerica) are commercialized in Brazil as $R$. solanacearum resistant rootstocks, few rootstocks available in the market are in fact resistant to bacterial wilt (Lopes et al., 2015). In this aspect, the mini-tomato accession RVTC-66 is an effective alternative for tomato seedling producers, considering it presented high morphological and anatomical affinity with scions of tomato and commercial yield similar to that of self-grafting, but with higher plant health index. Besides, the accession is not a commercial hybrid. Therefore, seed purchasing will not represent a significant additional cost in the production of grafted seedlings. However, it is advisable to evaluate RVTC-66 as a rootstock source also in other zones such as the North and Northeast regions of Brazil, where the prevalence of $R$. solanacearum may be even higher than the observed in this work.

\section{REFERENCES}

ABDELMAGEED, AHA; GRUDA, N. 2009. Influence of grafting on growth, development and some physiological parameters of tomatoes under controlled heat stress conditions. European Journal of Horticultural Science 74: 16-20.

ALMONEAFY, AA; OJAGHIAN, MR; XU, S; IBRAHIM, M; XIE, G; SHI, Y; TIAN, W; LI, B. 2013. Synergistic effect of acetylsalicylic acid and DL-Beta-aminobutyric acid on biocontrol efficacy of Bacillus strains against tomato bacterial wilt. Tropical Plant Pathology 38: 102-113.

ANDRIOLO, JL. 1999. Fisiologia das culturas protegidas. Santa Maria: UFSM. 142p.

FAO (Roma, Italy). World reference base for soil resources: draft. Paris: UNESCO, 1994. 161p.

FARIAS, EAP; FERREIRA, RLF; NETO, SEA; COSTA, FC; NASCIMENTO, DS. 2013. Organic production of tomatoes in the Amazon region by plants grafted on wild Solanum rootstocks. Ciência e Agrotecnologia 37: 323-329.

FLAISHMAN, MA; LOGINOVSKY, K; GOLOBOWICH, S; LEV-YADUN, S. 2008. Arabidopsis thaliana como um sistema modelo para o desenvolvimento da união do enxerto em homoenxertos e heteroenxertos. Jornal do Regulamento Planta de crescimento 27: 231-239.

FLORES, FB; BEL, OS; ESTAÑ, MT; RODRIGUEZ, MMM; MOYANO, E; MORALES, B; CAMPOS, JF; ABELLÁN, JOG; EGEA, MI; GARCIA, NF; ROMOJARO, F; BOLARÍN, MC. 2010. The effectiveness of grafting to improve tomato fruit quality. Scientia Horticulturae 125: 211-217.

GIACOBBO, CL; FACHINELLO, JC; PICOLOTTO, L. 2007. Compatibilidade entre o marmeleiro porta-enxerto cv. EMC e cultivares de pereira. Scientia Agraria 8: 33-37.

GILARDI, G; GULLINO, ML; GARIBALDI, A. 2013. Critical aspects of grafting as a possible strategy to manage soil-borne pathogens. Scientia Horticulturae 149: 19-21.

GOTO, R; SIRTOLI, LF; RODRIGUES, JD; LOPES, MC. 2010. Produção de tomateiro, híbrido Momotaro, em função do estádio de mudas e da enxertia. Ciência e Agrotecnologia 34: 961-966.

JAIMEZ, RE; RADAB, F; GARCÍA-NÚÑEZ, BC; AZÓCARB, A. 2005. Seasonal variations in leaf gas exchange of plantain cv. 'Hartón' (Musa AAB) under different soil water conditions in a humid tropical region. Scientia Horticulturae 104: 79-89.

KAWAGUCHI, M; TAJI, A; BACKHOUSE, D; ODA, M. 2008. Anatomy and physiology of graft incompatibility in solanaceous plants.
The Journal of Horticultural Science \& Biotechnology 83: 581-588.

LEE, JM; KUBOTA, C; TSAO, SJ; BIE, Z; ECHEVARRIA, PH; MORRA, L; ODA, M. 2010. Current status of vegetable grafting: Diffusion, grafting techniques, automation. Scientia Horticulturae 127: 93-105.

LOPES, CA; BOITEUX, LS; ESCHEMBACK, V. 2015. Eficácia relativa de porta-enxertos comerciais de tomateiro no controle da murcha-bacteriana. Horticultura Brasileira 33: $125-130$.

MARTÍNEZ-BALLESTA, MC; ALCARAZLÓPEZ, C; MURIES, B; MOTA-CADENAS, C; CARVAJAL, C. 2010. Physiological aspects of rootstock-scion interactions. Scientia Horticulturae 127: 112-118.

NODA, H; PALHEN, AVD; SILVA FILHO, DF. 1986. Avaliação de resistência de progênies de tomate à murcha bacteriana em solo naturalmente infestado por Pseudomonas solanacearum (Smith) Dows. Revista Brasileira de Genética 9: 55-56.

PEIL, RMA. 2003. Enxertia na produção de mudas de hortaliças. Ciência Rural 33: 1169-1177.

PENA, MAA; NODA, H; MACHADO, FM; PAIVA, MSS. 2010. Adaptabilidade e estabilidade de genótipos de tomateiro sob cultivo em solos de terra firme e várzea da Amazônia infestados por Ralstonia solanacearum. Bragantia 69: 27-37.

PETRAN, A; HOOVER, E. 2014. Solanum torvum as a compatible rootstock in interspecific tomato grafting. Journal of Horticulture 103: $1-4$.

PLANK, JE.1963. Plant disease: Epidemic and control. New York: Academic Press. 349p.

RODRIGUES, AC; MACHADO, LB; CAMPOS, AD; FACHINELLO, JC; FORTES, GRL. 2001. Avaliação da compatibilidade da enxertia em Prunus sp. Revista Brasileira de Fruticultura 23: 359-364.

SANTA-CRUZ, A; MARTINEZ-RODRIGUEZ, MM; PEREZ-ALFOCEA, F; ROMEROARANDA, R; BOLARIN, MC. 2002. The rootstock effect on the tomato salinity response depends on the shoot genotype. Plant Science 162: 825-831.

SILVA, FAS. ASSISTAT: Versão 7.7 beta. DEAGCTRN-UFCG - Atualizado em 01 de abril de 2014. Available at $<\mathrm{http}: / /$ www.assistat.com/ $>$. Accessed May 20, 2014.

VENEMA, JH; BOUKELIEN, ED; BAX, JEM; HASSELT, PRV; ELZENGA, JTM. 2008. Grafting tomato (Solanum lycopersicum) onto the rootstock of a high-altitude accession of Solanum habrochaites improves suboptimaltemperature tolerance. Environmental and Experimental Botany 63: 359-367. 